\title{
IFRS 9 Single Impairment Model: Semantics and Circularity? A Study in the Airline Industry
}

\author{
Francesco Bellandi ${ }^{1}$ \\ ${ }^{1}$ Head of Technical Accounting, Multinational, London, UK \\ Correspondence: Francesco Bellandi, Head of Technical Accounting, Multinational, London, UK. E-mail: \\ Francesco_bellandi@yahoo.com
}

Received: August 20, 2021

Accepted: October 26, 2021

Online Published: November 12, 2021

doi:10.5539/ijbm.v16n12p41

URL: https://doi.org/10.5539/ijbm.v16n12p41

\begin{abstract}
This paper studies a sample of airlines reporting under International Financial Reporting Standards (IFRS) about three specific challenges in implementing International Accounting Standards Board (IASB) (2019), IFRS 9 requirements for impairment versus IASB, 2014, IAS 39: 1) expected versus incurred credit losses; 2) impairment scoping and elective simplifications; and 3) definition and use of default. First, there appears to be a strong indicator that the way airline companies have drawn the line between what future conditions should or should not be considered in estimating expected versus incurred credit losses has maintained the fundamental tenet in IFRS of representing the condition existing as of the end of the reporting period. Second, evidence of companies quests for IASB (2019), IFRS 9 impairment simplifications attests to the criticism that the alleged single model of impairment is in effect a complex collection of different techniques. Finally, the degree of specific application that IASB (2019), IFRS 9 requires for the definition and use of default, as well as the customization of what triggers a significant change in the risk of default since initial recognition, does not appear to have been fully received, and sufficiently disclosed in the financial statements.
\end{abstract}

Keywords: IFRS 9, impairment, airline, default, expected credit loss

\section{Introduction}

\subsection{What the Problem Is and Why It Is Important}

IASB, IFRS 9 in its 2014 version became effective on 1 January 2018. A single impairment model for all financial assets not measured at fair value is known to be one of the innovations of the standard as compared to IASB (2014), IAS 39 (IASB, 2019, IFRS 9.BC4.1.b). This novelty was intended as part of a stream of actions to eliminate much of the complexity in IASB (2014), IAS 39, partly because of reducing the number of classification categories for financial assets (IASB, 2019, IFRS 9.BC4.2, BC5.121). The IASB claims that such an outcome has been reached by using the same impairment model for both financial assets at amortized cost and financial assets at fair value through other comprehensive income, a fact which would enhance comparability of amounts that are recognized in profit or loss for assets with similar economic characteristics (IASB, 2019, IFRS 9.BC5.124).

This paper studies how IFRS financial statement preparers have faced three specific challenges in implementing the new IASB (2019), IFRS 9 requirements for impairment: 1) where to draw the line in estimating expected versus incurred credit losses under previous IASB (2014), IAS 39; 2) how to scope the items to which different impairment rules apply and whether to take elective simplifications; and 3) how to apply the definition and use of default under IASB (2019), IFRS 9. This article intends to study how a sample of companies in the airline industry have dealt with these three critical aspects.

These points are important for both academic, companies and practitioners, because the new standard represents a major change in assessing impairment of financial instruments, which has by far been one of the most significant and debated controversies since the 2008 financial crisis, triggering revisions of accounting standards in the aftermath. Testing companies practice is important because it tells whether the new impairment model works in practice and whether and how it has been received by companies. Now that the adoption of IASB (2019), IFRS 9 is over, but its requirements are ongoing, more research is needed because company practice is key for reviewing whether the tenets of IASB (2019), IFRS 9 hold and whether they should be adjusted in its post-implementation review. To that respect, the IFRS Foundation has recently issued a call for academic research, focusing specifically 
on the quality of disclosures provided by companies applying IASB (2019), IFRS 9. Most studies on the new standard have focused on banks and financial institutions. However, in academic research excluding other industries simply on the assumption that a subject is not significant is not acceptable, as this must be proved. In addition, while other industries might have a lower absolute value of financial instruments, the impact of IASB (2019), IFRS 9 impairment in percentage of financial instruments is still to be seen. Therefore, more work is needed in other industries and sectors.

\subsection{Relationship to Previous Work in the Area}

There are other works on IASB (2019), IFRS 9 (see literature review), although they are not focused only on the impairment aspect. As mentioned, there is a lack of IASB (2019), IFRS 9 literature in industries other than banks and financial institutions. In particular, the author has not found any study on the IASB (2019), IFRS 9 impairment in the airline sector. However, there is research in that sector on other aspects, so the author has reviewed and adapted samples of companies used in previous research.

\subsection{Hypotheses and Objectives of the Study and Theoretical and Practical Implications}

A hypothesis of the study is that observing how companies have implemented IASB (2019), IFRS 9 may give some insights on whether certain alleged criticalities of the standard are real, as well as how companies have managed to live with them. The objective of the study is to draw from there and extrapolate on certain theoretical aspects that have tangled IASB (2019), IFRS 9.

First, the paragraph on the research questions explains how the objective of verifying the gap between expected credit loss and the incurred credit loss model (IASB, 2014, IAS 39) draws back to a dichotomy between IASB (2019), IFRS 9 and IASB (2018), IAS 10, which anchors to a long-lasting debate between the balance sheet approach, where profit or loss results from assets and liabilities definition, versus the income approach, where balance sheet position results from value estimates of oncoming profit or loss items (circularity). The study of where companies have drawn the line between what future conditions should or should not be considered in estimating expected versus incurred credit losses (under IASB, 2014, IAS 39) may shed a light on the IFRS dichotomy of representing the condition existing as of the end of the reporting period versus forms of incorporating forward-looking information in applying IASB (2019), IFRS 9.

Second, the paragraph on the research questions goes on with the issue of whether the IASB (2019), IFRS 9 model really is a single model of impairment, as claimed. A review of the use of IASB (2019), IFRS 9 impairment simplifications in company practice could attest to that respect.

Finally, IASB (2019), IFRS 9 gives considerable freedom to a company in setting its own definition of default and use of this concept. After explaining the theoretical underpinnings that make the issue complicated for implementing such a concept, the study of company practice intends to check whether such a freedom has translated into customized faithful representation and disclosure or, on the contrary, to ambiguity for financial statement preparers and readers.

\section{Research Questions and Links to Theory}

\subsection{Present vs. Future Conditions in Expected versus Incurred Credit Loss}

IASB (2014), IAS 39 features a so-called "incurred credit losses" model, whereby a credit event must have occurred before credit losses can be recognized. IASB (2014), IAS 39, paras. 58-59 require objective evidence of impairment, by means of a "loss event", which must have occurred after the initial recognition of the asset (i.e., a past event as at the reporting date). Recognition of losses expected because of future events is prohibited (IASB, 2014, IAS 39, para. 59). Possible or expected future trends are not objective evidence of impairment (IASB, 2014, IAS 39, para. BC110). On the other hand, IASB (2019), IFRS 9 moves to an expected credit losses model (IASB, 2019, IFRS 9, para. 5.5.1), which is intended to address issues of the incurred credit losses model, namely the fact that it has been accused of delaying the recognition of credit losses and overstating interest revenue where an expected credit loss is unreported (IASB, 2019, IFRS 9, para. BC5.83). While in defining credit losses both IASB (2014), IAS 39 and IASB (2019), IFRS 9 consider prospective cash flows (IASB, 2014, IAS 39, para. 63: "estimated" future cash flows, IASB (2019), IFRS 9. Appendix A: cash flows expected to receive), the definition of expected credit losses in IASB (2019), IFRS 9 is a statistical expected value (i.e., a probability-weighted of possible outcomes). Therefore, the effect of possible, not occurred events is implicit in the definition. IASB (2019), IFRS 9, para. 5.5.17 also requires consideration of future economic conditions, not simply the future impact of past events and current conditions.

A theoretical issue is whether the expected credit losses model is consistent with IASB (2018), IAS 10, based on which, for a subsequent event to be an adjusting event, it must provide evidence of conditions that existed at the 
end of the reporting period (IASB, 2018, IAS 10, para. 3). IASB (2018), IAS 10, para. 9 states, by means of example, that the bankruptcy of a customer that occurs after the reporting but before the date of issuance of the financial statements is an adjusting event to the extent it confirms that the customer was credit-impaired at the end of the reporting period. As a compromise in the aftermath of the financial crisis, it might be possible that the IASB (2019), IFRS 9 expected credit loss would not under all circumstances meet the rigorous cut-off of IASB (2018), IAS 10, which is also widely and consistently applied in other contexts by the other IFRSs. However, if on one hand information must include forecasts of future economic conditions, IASB (2019), IFRS 9, para. BC283 also notes that such information must be based on information, circumstances, and events available at the reporting date.

Therefore, the first research question is how the sampled companies have adopted forward-looking estimation guidelines for the new expected credit loss requirements in IASB (2019), IFRS 9 as opposed to the incurred credit loss requirements in IASB (2014), IAS 39. If the impairment impact of IASB (2019), IFRS 9 versus IASB (2014), IAS 39 as of the adoption date is significant, it might be inferred that there are substantial differences in the measurement methods, horizons, and factors that are taken into consideration. If it is negligible, this might be a strong indicator that the requirements of IASB (2019), IFRS 9 and/or the way it is implemented do not use forwardlooking information in a manner that violates the basic tenet of information about conditions that existed at the end of the reporting period in IASB (2018), IAS 10 and the other IFRSs.

\subsection{Single Method of Impairment}

The IASB (2019), IFRS 9 claim for a single impairment model may appear to be a matter of semantics. In fact, to a greater scrutiny, the IASB (2019), IFRS 9 impairment model has a plethora of facets, which make it not really a single impairment model. Hence, the second research question is what degree of simplification the sampled companies have taken to implement the impairment requirements in IASB (2019), IFRS 9. Accommodations they have elected may be an indication of both complexity of the standard and whether its alleged single method of impairment really is such.

To link to the theory, IASB (2014), IAS 39 has an impairment model for financial assets carried at amortized cost, and specific methods for financial assets carried at cost and for available-for-sale financial assets. The model for impairment of financial assets carried at amortized cost is the standard approach, namely applicable to held-tomaturity investments and loans and receivables (IASB, 2014, IAS 39.8, 46, 63). Conversely, the IASB (2019), IFRS 9 single impairment model applies to financial assets that are measured at amortized cost, at fair value through other comprehensive income, lease receivables, IFRS 15 contract assets, loan commitments, and financial guarantee contracts (IASB, 2019, IFRS 9, para. 5.5.1). Under IASB (2014), IAS 39, an impairment of availablefor-sale financial assets triggers a reclassification adjustment from accumulated other comprehensive income into profit or loss, for the difference between current fair value and net carrying amount of the instrument (acquisition cost, minus any principal repayment and amortization, minus any previously recognized impairment loss) (IASB, 2014, IAS 39, paras. 67-68). Under IASB (2019), IFRS 9, available-for-sale financial assets do not exist any longer. IASB (2019), IFRS 9 financial assets measured at fair value through other comprehensive income are not equivalent to IASB (2014), IAS 39 available-for-sale financial assets, as such classification arises from their contractual cash flow characteristics and their respective business model and not as a matter of residual classification (IASB, 2019, IFRS 9, paras. BC4.161, BCE.25). Financial assets measured at amortized cost and at fair value through other comprehensive income (FVTOCI) (IASB, 2019, IFRS 9, para. 4.1.2A) now share the same impairment methodology (IASB, 2019, IFRS 9, para. 5.2.2). The justification follows several rationales. First, although the IASB (2019), IFRS 9 newly developed impairment model is a larger construct, an amortized costbased notion is still central to it. The IASB asserts that for both FVTOCI and financial assets at amortized cost the amounts recognized in profit or loss must be the same (IASB, 2019, IFRS 9, paras. 5.7.10-5.7.11). Second, as the quantification of interest income and foreign exchange gains and losses follows a like computation, hence the mechanics of impairment gains and losses must be the same. Furthermore, the IASB signposts the objective of the FVTOCI category as to inform readers of financial statements about both fair value and amortized cost (IASB, 2019, IFRS 9, para. BC5.119). Fourth, the IASB (2019), IFRS 9 general impairment model focuses on management's assessment of the changes in the risk of a default occurring since initial recognition, not on market participants' view of fair value (IASB, 2019, IFRS 9, paras. BC5.122-5.123). Finally, as both categories share collecting contractual cash flows as part of their business models, the effect of changes in credit risk are similarly relevant (IASB, 2019, IFRS 9.BC5.82).

However, at a closer look, that single model has so many different angles that may be considered as different models in their own right: 
- the single model is in effect a dual model with an interplay of 12-month expected credit losses and lifetime expected credit losses;

- there is a simplified approach for certain assets, such as trade receivables under certain situations, which only considers lifetime expected credit losses;

- there is an assumption of no significant change in risk of default occurring for financial instruments that have low credit risk at the reporting date;

- there is a different treatment for purchased or originated credit-impaired financial assets, dictated by the need for a better representation the underlying economics of these financial assets (IASB, 2019, IFRS 9, para. BC5.215);

- there is a different presentation for financial assets measured at fair value through other comprehensive income;

- there is a removal of the impairment issue from certain instruments by simply classifying them into the fair value arena;

- there are specific considerations for loan commitments and financial guarantees.

In addition, there are a series of specific treatments, as explained below.

IASB (2019), IFRS 9 retains the accounting in IASB (2014), IAS 39 for loan commitments and financial guarantee contracts, but it brings those that are not measured at fair value through profit or loss within the scope of the impairment model (IASB, 2019, IFRS 9, paras. 5.5.1, BC2.8, BC2.17, BC5.118), even if they are otherwise scoped out of the standard (IASB, 2019, IFRS 9, para. 2.1(g)). In assessing the risk of a default associated with the credit exposure of an issuer of a loan commitment, the standard refers to the loan to which a loan commitment relates. For a financial guarantee contract, it points to the changes in the default risk of the guaranteed debtor (IASB, 2019, IFRS 9, para. B5.5.8).

Under IASB (2014), IAS 39, a financial asset carried at cost includes an unquoted equity instrument where its fair value cannot be reliably measured, or a derivative asset that is linked to and must be settled by delivery of such an unquoted equity instrument (IASB, 2014, IAS 39, para. 46). For such an instrument, an impairment loss corresponds to its carrying amount less the present value of estimated future cash flows discounted at the current market rate of return (IASB, 2014, IAS 39, para. 66), as opposed to the effective interest rate computed at initial recognition for financial assets carried at amortized cost. The need for a separate impairment model was due to measurement at amortized cost not being applicable to equity investments (IASB, 2019, IFRS 9, para. BC5.13). In fact, as equity instruments, they do not have contractual cash flows, and as they are measured at cost, there is no need to compute an effective interest rate at initial recognition. In IASB (2019), IFRS 9, such a category does not exist any longer, as the standard requires all equity investments and derivatives on them to be measured at fair value and removes their measurement exception. Therefore, in this respect, the simplification of the impairment methodology established by IASB (2019), IFRS 9 arises from the new classification of financial assets. Being measured at fair value, they are no longer caught up by the impairment requirements, which do not apply to instruments carried at fair value (IASB, 2019, IFRS 9, para. 5.5.1).

The IASB also arguments that for not-held-for-trading equity investments, the irrevocable election to present subsequent fair value changes in other comprehensive income (IASB, 2019, IFRS 9, paras. 4.1.4, 5.7.5) and the prohibition on recycling other comprehensive income (OCI) into profit or loss (IASB, 2019, IFRS 9, para. B5.7.1) avoid reintroducing a need for impairment accounting (IASB, 2019, IFRS 9, paras. BC5.25.b, BCE.67). On the flip side, this again appears to be an additional model that uses OCI as a practical expedient not grounded on any solid conceptual justification.

\subsection{Definition and Use of Default}

The third research question is how the sampled companies have dealt with the subjectivity of the definition of default intentionally maintained in IASB (2019), IFRS 9, and to what extent they have disclosed their definition and use of default.

To explain the theory, IASB (2019), IFRS 9 uses the term "default" twofold: 1) as part of the definition and measurement of expected credit losses, and 2) for the purpose of monitoring whether the risk of a default occurring has increased significantly since initial recognition. As to the former, expected credit losses are defined as the weighted average of credit losses with the respective risks of a default occurring as respective weights. Lifetime expected credit losses result from all possible default events over the expected life of a financial instrument, while 12-month expected credit losses are the portion of them that result from possible default events within the 12 months after the reporting date (IASB, 2019, IFRS 9, para. Appendix A). So, similarly to IASB (2014), IAS 39, 
for the purpose of measurement, default events trigger credit losses. Under both standards, credit losses are based on estimated cash flows, but under IASB (2014), IAS 39 loss events are actual while under IASB (2019), IFRS 9 default events may be possible. As to the latter use of the term "default", IASB (2019), IFRS 9 moves the focus from default events as a trigger of an impairment loss recognition (as in IASB, 2014, IAS 39) to the notion of significant change in the risk of a default occurring since initial recognition, which prompts the move from the use of 12-month expected credit losses to lifetime expected credit losses (IASB, 2019, IFRS 9, paras. 5.5.9, B5.5.7). This is not determined based on the change in expected credit losses, or evidence of a financial asset being creditimpaired at the reporting date, or an actual default occurring.

Under IASB (2014), IAS 39, a loss event must be supported by objective evidence that is corroborated by current observable data (IASB, 2014, IAS 39, paras. 58-59, BC110). Unlike IASB (2014), IAS 39, IASB (2019), IFRS 9 intentionally does not define a default event (IASB, 2019, IFRS 9, para. BC5.252). It defines principles, though. An entity must apply a default definition that is consistent with the definition used for internal credit risk management for that instrument, and consider qualitative indicators (e.g., financial covenants) when appropriate (IASB, 2019, IFRS 9, para. B5.5.37). It must apply an impairment model in a way that provides useful information about actual credit risk management (IASB, 2019, IFRS 9, para. BC5.251). It should also apply the definition consistently to all financial instruments, unless it demonstrates that other definitions more appropriately apply to a particular instrument (IASB, 2019, IFRS 9, para. BC5.252). IASB (2014), IAS 39 provides a list of objective evidence of loss events. For an investment in an equity instrument, IASB (2014), IAS 39 has additional events that were considered as objective evidence of impairment, over and above that list. While under IASB (2014), IAS 39 loss events were focused on past events that evidence default, under IASB, 2019, IFRS 9 information about change in risk of default occurring is centered on information on past, current and forward-looking conditions. Such information must be reasonable and supportable, and companies must use it to the extent it is available without undue cost or effort at the reporting date (IASB, 2019, IFRS 9, para. 5.5.17).

\section{Literature Review}

Several studies are on IASB (2019), IFRS 9 in general, as compared to IASB (2014), IAS 39. For example, Mechelli et al. (2020a) conclude that IASB (2019), IFRS 9 is more relevant than IASB (2014), IAS 39 in countries with high-quality corporate governance and investor protection, whereas it is the opposite in countries where such a quality is low. According to Knežević et al. (2015), the change from IASB (2014), IAS 39 to IASB (2019), IFRS 9 did not meet the goals regarding comparability of financial statements and possible earnings volatility.

As to expected credit loss, Camfferman (2015) illustrates the historical journey of the incurred loss in IASB (2014), IAS 39 versus an expected loss model. Giner et al. (2019) contrast the features and consequences of the new model with the incurred credit loss, analyze the controversies with bank prudential institutions, information asymmetry and conservatism. Cohen et al. (2014) and Morris et al. (2016) focus on bank earning management practices. Stander (2021) elaborates on the impact of IASB (2019), IFRS 9 impairment volatility on earnings quality. Gebhardt (2016), in analyzing the Greek crisis, finds an increased discretion of preparers in estimating impairment as compared to IASB (2014), IAS 39.

Banks and financial institutions have been one of the main objects of analysis on IASB (2019), IFRS 9 impairment. Bushman et al. (2012) finds that bank management discretion is a key determinant in the way of using forwardlooking information in an incurred loss model. Abad et al. (2017) and Goma et al. (2019) anticipate an increase in impairment. Zaman Groff et al. (2020) investigate singularities related to institutional and regulatory setting for Slovenian banks. Seitz et al. (2018) find that expected credit loss provisions have been not necessarily higher than IASB (2014), IAS 39, although they are much more sensitive to assumptions and inputs used, and they are volatile on market environment changes.

Most IASB (2019), IFRS 9 industry surveys are on banks and financial institutions. Industries other than banks and financial institutions have been touched lightly by academic research. Löw et al. (2019) find that the total amount of loan loss reserves has decreased for European banks. Mechelli et al. (2020b) show a slight reduction in equity for a sample of bank and financial institutions. The Financial Reporting Council (FRC) (2018) survey of interim disclosures of companies in banking, oil and gas, insurance, travel and leisure, and mining finds that no company adopted IFRS 9 by full retrospective method with restatement of comparative information. Impairment requirements had generally no material impact in non-bank entities. Unlike most banks, which did not provide detail of their key assumptions on transition and significant change in credit risk, non-banking entities provided some helpful disclosures. The FRC noted that when impact is not material, it expects reasons to be disclosed. Aranda et al. (2020) treat the energy sector in Brazil, finding that the expected credit loss adjustments were not relevant. Finally, literature review search for this article has not found any academic contribution that is relevant 
to the impairment impact to the airline industry, which is the industry studied in this paper.

\section{Research Method}

The analysis is conducted through a review of the financial statements (publicly available from the Internet), starting from the 53 sampled airlines used in Bellandi (2019). That sample considered the top 10 airlines by revenue, the top 10 airlines by passengers, top 10 U.S. airlines, and the top 10 European airlines. It then took the top 10 airlines of the survey of the World's Top 100 Airlines. Then, from the same survey it selected a random sample of at least 2 companies for each 10 rankings through random representation of the remaining population (e.g., at least 2 out of the companies ranking from 11 to 20, at least 2 from 21 to 30, etc.). To comprise companies ranked below 100 , other companies were included.

That initial sample has been modified to consider only IFRS preparers (given that this study is on IASB, 2019, IFRS 9), and for the follows additional factors:

\begin{tabular}{lc}
\hline & $\begin{array}{c}\text { No. } \\
\text { companies }\end{array}$ \\
\hline $\begin{array}{l}\text { Initial sample (top } 10 \text { airlines by revenue, the top } 10 \text { airlines by passengers, top 10 U.S. airlines, and the top 10 European } \\
\text { airlines, additional random sample) }\end{array}$ & 53 \\
Less: non-IFRS preparers (Air Asia, Air China, Hainan Airlines, Air India, Jet Airways, Garunda Indonesia, Aeroflot, \\
Alaska Air, Allegiant Airlines, American Airlines, Cargo Jet, Delta Air Lines, Hawaiian, JetBlue, Republic Airways, \\
Southwest Airlines, Spirit Airlines, United Continental) \\
Less: financial statements not available because of bankruptcy and similar procedures (Air Berlin, Alitalia, Flybe, \\
Meridiana Fly) & -4 \\
Less: financial statements for adoption year not found available for download (Oman Air, Air Malta) & -2 \\
Less: financial statements that do not show any adoption of IFRS 9 (Iberia, Vueling) & -2 \\
Final net sample & 27 \\
\hline
\end{tabular}

Data has been analyzed through reading and elaboration of the financial statement accounts and note disclosures.

\section{Results and Discussion}

Table 1 first shows the impact on trade and other receivables of the IASB (2019), IFRS 9 initial adoption impairment adjustment. The research hypothesis is that in companies practice an impact below $10 \%$ would generally be considered not significant. Table 1 shows an impact from $-1.5 \%$ to $0.1 \%$, with an average of $-0.8 \%$. $63 \%$ of the sampled companies declare the impact nil or not significant. $4 \%$ have not disclosed the impact, which may make think it must be not significant either. As a reference, the table also indicates the impact of the overall adoption of IASB (2019), IFRS 9 (not the subject of this article) on total equity as well as on retained earnings, which is affected by several aspects other than impairment, such as reclassification of financial assets, fair value adjustments, hedge accounting, etc. All these factors in general weight much more than impairment, making the range spanning from $-10.2 \%$ to $12.1 \%$ of retained earnings, and from $-1.3 \%$ to $1.7 \%$ of total equity, although over a quarter of the entities still declare the impact as not significant, with an additional significant portion of no disclosure (15\% and $30 \%$, respectively). Change in equity versus retained earnings is smaller due to the offset by changes in accumulated other comprehensive income following reclassifications of financial instruments.

Table 1. Impact of applying IFRS 9

\begin{tabular}{llll}
\hline & $\begin{array}{l}\text { Impairment on } \\
\text { trade and other } \\
\text { receivables }\end{array}$ & $\begin{array}{c}\text { On equity } \\
\text { earnings }\end{array}$ & $-0.9 \%$ \\
\hline Aegean Airlines & $-1.5 \%$ & n.a. & n.s. \\
Air Arabia & n.s. & n.a. & n.s. \\
Air Canada & n.s. & n.a. & n.a. \\
Air France KLM & n.s. & n.s. & n.s. \\
Air Lingus & n.s. & n.a. & $0.0 \%$ \\
British Airways Plc & n.s. & n.s. & $0.0 \%$ \\
Cathay Pacific & $-1.5 \%$ & $1.1 \%$ & $-0.2 \%$ \\
China Eastern & n.s. & $0.2 \%$ & $0.2 \%$ \\
China Southern Airlines & $0.0 \%$ & $0.0 \%$ & $0.0 \%$ \\
Comair & & & \\
\hline
\end{tabular}




\begin{tabular}{llll}
\hline EasyJet & n.s. & $1.7 \%$ & $2.5 \%$ \\
El Al Israel Airlines & n.s. & n.a. & n.s. \\
Emirates & n.s. & $0.2 \%$ & $0.2 \%$ \\
EVA Air & $0.0 \%$ & $0.0 \%$ & $5.2 \%$ \\
Finnair & $-1.2 \%$ & $-0.1 \%$ & $12.1 \%$ \\
International Airlines Group & $-1.0 \%$ & n.a. & n.a. \\
Lufthansa Group & $-0.2 \%$ & $0.0 \%$ & $3.7 \%$ \\
Norwegian Air Shuttle & n.s. & $0.0 \%$ & $0.0 \%$ \\
Qantas & n.s. & n.a. & n.a. \\
Qatar Airways & $0.1 \%$ & $-0.1 \%$ & $-10.2 \%$ \\
Ryanair & n.s. & $0.0 \%$ & n.s. \\
SAS & $-1.2 \%$ & $0.0 \%$ & $-6.3 \%$ \\
Singapore Airlines & n.a. & n.a. & n.a. \\
Turkish Airlines & $-1.1 \%$ & $-0.1 \%$ & $-0.2 \%$ \\
Virgin Australia & $-0.8 \%$ & $-0.1 \%$ & $0.1 \%$ \\
West Jet & n.s. & n.s. & n.s. \\
Wizz Air & n.s. & $0.0 \%$ & $-0.8 \%$ \\
Min & $-1.5 \%$ & $-1.3 \%$ & $-10.2 \%$ \\
Max & $0.1 \%$ & $1.7 \%$ & $12.1 \%$ \\
Average & $-0.8 \%$ & $0.1 \%$ & $0.3 \%$ \\
Number of occurrences that disclose as nil or not significant & $63 \%$ & $37 \%$ & $37 \%$ \\
Number of occurrences that do not disclose & $4 \%$ & $30 \%$ & $15 \%$ \\
\hline
\end{tabular}

Notes. n.s: not significant (i.e., disclosed as no significant impact or similar expressions).

n.a.: not available (i.e., not disclosed in the financial statements).

In relation to the first research question, there appears to be a strong indicator that the conditions that existed at the end of the reporting had been precisely represented in the un-restated statements under IASB (2014), IAS 39, to approximate the measurement based on reasonable and supportable information that have been then considered under IASB (2019), IFRS 9 for the restated statements on the same date. Table 1 shows that the impact impairment adjustment on trade and other receivables of the adoption of IASB (2019), IFRS 9 has been very contained, and for more than half to $2 / 3$ of the sample not significant or not worth disclosing. Of course, this may be part of the explanation, conceivably not excluding cases of poor determination under IASB (2019), IFRS 9, or unwillingness to report higher impairment losses in the financial statements.

Table 2 illustrates the extent to which IASB (2019), IFRS 9 adopters have used certain simplifications in relation to the new impairment requirements. The research hypothesis is that a predominance criterion (i.e., more than $50 \%$ ) would indicate a significant propensity to simplification or, symmetrically, a criticism against a complex, fullyfledged accounting. $85 \%$ of the sampled companies have explicitly disclosed in their financial statements their election of the simplified approach for trade and other receivables, and 59\% in conjunction with a provision matrix. $37 \%$ have disclosed to have elected the low-risk simplification. 56\% have made an irrevocable election at initial recognition for non-held for trading equity instruments to present subsequent changes in fair value in other comprehensive income. However, in Table 2 "no" also includes situations where no disclosure has been found in the financial statements on whether the company has made a certain election, a fact which often covers cases where the company does not have the items that are treated by that specific election, not necessarily that it did not want to opt for it. As a reference, $70 \%$ of the sampled companies have adopted IASB (2019), IFRS 9 by not recasting comparative information. 
Table 2. Simplification elections

\begin{tabular}{|c|c|c|c|c|c|}
\hline Election for: & $\begin{array}{l}\text { Trade } \\
\text { Receivables } \\
\text { Simplified } \\
\text { Approach } \\
\end{array}$ & $\begin{array}{l}\text { Provision } \\
\text { Matrix }\end{array}$ & $\begin{array}{l}\text { Low Risk } \\
\text { Simplification }\end{array}$ & $\begin{array}{l}\text { Equity } \\
\text { Instruments with } \\
\text { Changes in Fair } \\
\text { Value in OCI }\end{array}$ & Transition Method \\
\hline Aegean Airlines & Yes & Yes & Yes & No & Modified retrospective \\
\hline Air Arabia & Yes & Yes & No & Yes & Modified retrospective \\
\hline Air Canada & Yes & No & No & Yes & Modified retrospective \\
\hline Air France KLM & Yes & No & No & Yes & Retrospective \\
\hline Air Lingus & Yes & Yes & No & No & Retrospective \\
\hline British Airways & Yes & Yes & No & Yes & Retrospective \\
\hline Cathay Pacific & Yes & Yes & No & Yes & Modified retrospective \\
\hline China Eastern & Yes & Yes & No & Yes & Modified retrospective \\
\hline China Southern Airlines & Yes & Yes & Yes & Yes & Modified retrospective \\
\hline Comair & Yes & Yes & yes & No & Modified retrospective \\
\hline EasyJet & Yes & No & No & Yes & Modified retrospective \\
\hline El Al Israel Airlines & No & No & No & No & Modified retrospective \\
\hline Emirates & Yes & No & yes & No & Not mentioned \\
\hline EVA Air & Yes & Yes & yes & Yes & Modified retrospective \\
\hline Finnair & Yes & Yes & yes & No & Modified retrospective \\
\hline International Airlines Group & Yes & Yes & No & Yes & Retrospective \\
\hline Lufthansa Group & Yes & Yes & No & Yes & Modified retrospective \\
\hline Norwegian Air Shuttle Asa & Yes & Yes & No & Yes & Retrospective \\
\hline Qantas & No & No & No & No & Modified retrospective \\
\hline Qatar Airways & Yes & Yes & yes & Yes & Retrospective \\
\hline Ryanair & No & No & No & No & Modified retrospective \\
\hline SAS & Yes & No & No & No & Modified retrospective \\
\hline Singapore Airlines & Yes & No & yes & Yes & $\begin{array}{l}\text { As part of IFRS First Time } \\
\text { Adoption }\end{array}$ \\
\hline Turkish Airlines & Yes & Yes & yes & Yes & Modified retrospective \\
\hline Virgin Australia & Yes & Yes & No & No & Modified retrospective \\
\hline West Jet & Yes & No & Yes & No & Modified retrospective \\
\hline Wizz Air & No & No & No & No & Modified retrospective \\
\hline Yes & $85 \%$ & $59 \%$ & $37 \%$ & $56 \%$ & \\
\hline No & $15 \%$ & $41 \%$ & $63 \%$ & $44 \%$ & \\
\hline Modified retrospective & & & & & $70 \%$ \\
\hline Retrospective or as part of IF & st Time Adop & & & & $30 \%$ \\
\hline
\end{tabular}

The picture that comes out goes in the same direction as the above-mentioned perception that the alleged single model of impairment is in effect a collection of different techniques. Table 2 does confirm that IASB (2019), IFRS 9 adopters have searched for simplification, by availing themselves of several elections to make the accounting for impairment easier. It indirectly attests to the complexity of impairment under IASB (2019), IFRS 9. If the impairment requirements in IASB (2019), IFRS 9 were simple, accommodations would not be needed. Trade and other receivables predominantly follow the simplified approach, often in conjunction with the use of a provision matrix. The low-cost simplification has permitted companies to assume no significant increase in the risk of a default occurring since initial recognition. By the OCI election, certain equity instruments have been pushed out of the impairment requirements.

The research hypothesis related to Table 3 is that, as customization and disclosure of definition of default is required by the standard, the greater a deviance from $100 \%$ the greater the failure to provide users of financial statements with a key understanding of impairment policy and effects. As Table 3 illustrates, only $52 \%$ of the sampled companies have disclosed a definition of default in a way that is not simply a mere quotation or re- 
phrasing of IASB (2019), IFRS 9 language. This total includes 15\% using the rebuttable presumption in IASB (2019), IFRS 9 that default does not occur later than 90 days past due, 11\% adopting another threshold (e.g., 60 days or 365 days or 5 months overdue), 22\% defining default as an unqualified concept of recoverability becoming at risk (such as unlikelihood to pay obligations in full, without recourse, such as realizing security), and $4 \%$ reediting some IASB (2014), IAS 39 events of default. On the contrary, none but one company had disclosed a customized definition of default different from IASB (2014), IAS 39 wording.

In Table 3, only 33\% of the sampled companies have disclosed some customized definitions of what constitutes a significant change in the risk of default since initial recognition that does not simply duplicate IASB (2019), IFRS 9 language. This total includes 15\% using the rebuttable presumption in IASB (2019), IFRS 9 of significant risk increase when contractual payments exceed 30 days past due, $7 \%$ using an unqualified concept of recoverability becoming at risk (i.e., like what was mentioned before as a definition of default, but here in the context of assessing change in risk of default occurring), and 11\% reshuffling some IASB (2014), IAS 39 events of default in this new context. As a comparison with banks in the survey of European Banking Authority (EBA) (2018), 19\% of that sample used the 30-day past due backstop, and $26 \%$ the 90 -day past due backstop.

Table 3. Definitions and use of default

\begin{tabular}{|c|c|c|c|c|c|}
\hline & $\begin{array}{l}\text { Customized } \\
\text { Definition of Default } \\
\text { for Expected Credit } \\
\text { Losses }\end{array}$ & $\begin{array}{l}\text { Use of the 90-day } \\
\text { past due } \\
\text { Rebuttable } \\
\text { Presumption of } \\
\text { Default } \\
\end{array}$ & $\begin{array}{l}\text { Customized Definition of } \\
\text { Significant Change in the } \\
\text { Risk of Default since Initial } \\
\text { Recognition }\end{array}$ & $\begin{array}{l}\text { Use of the 30-day } \\
\text { Rebuttable } \\
\text { Presumption of } \\
\text { Significant Risk } \\
\text { Increase } \\
\end{array}$ & $\begin{array}{l}\text { Pre-IFRS } 9 \\
\text { Customized } \\
\text { Definition of } \\
\text { Default }\end{array}$ \\
\hline $\begin{array}{l}\text { Aegean } \\
\text { Airlines }\end{array}$ & No & Yes & $\begin{array}{l}\text { When collection problems of } \\
\text { contractual claims are } \\
\text { considered possible }\end{array}$ & No & No \\
\hline Air Arabia & Over 60 days past due & No & $\begin{array}{l}\text { Unlikelihood to receive the } \\
\text { outstanding contractual } \\
\text { amounts in full before any } \\
\text { credit enhancements }\end{array}$ & No & $\begin{array}{l}\text { Over } 180 \text { days } \\
\text { past due }\end{array}$ \\
\hline Air Canada & No & No & No & No & No \\
\hline $\begin{array}{ll}\text { Air } & \text { France } \\
\text { KLM } & \end{array}$ & No & No & No & No & No \\
\hline Air Lingus & No & No & No & No & No \\
\hline $\begin{array}{l}\text { British } \\
\text { Airways }\end{array}$ & No & Yes & No & No & No \\
\hline $\begin{array}{l}\text { Cathay } \\
\text { Pacific }\end{array}$ & $\begin{array}{l}\text { Unlikelihood to pay } \\
\text { obligations in full } \\
\text { without recourse, such } \\
\text { as realizing security }\end{array}$ & No & No & No & No \\
\hline China Eastern & $\begin{array}{l}\text { Contractual payments } \\
\text { past due, or } \\
\text { unlikelihood of full } \\
\text { payment of outstanding } \\
\text { contractual amounts } \\
\text { before credit } \\
\text { enhancements }\end{array}$ & No & No & No & No \\
\hline $\begin{array}{l}\text { China } \\
\text { Southern } \\
\text { Airlines }\end{array}$ & $\begin{array}{l}\text { Unlikelihood to pay } \\
\text { obligations in full, } \\
\text { without recourse to } \\
\text { actions, such as } \\
\text { realizing security }\end{array}$ & No & No & Yes & No \\
\hline Comair & $\begin{array}{l}\text { Trade and other } \\
\text { receivables being more } \\
\text { than five months past } \\
\text { due }\end{array}$ & No & $\begin{array}{l}\text { The financial position of the } \\
\text { counterparty; liquidity } \\
\text { constraints such as problems } \\
\text { servicing debt and } \\
\text { renegotiation of debt; re- }\end{array}$ & No & No \\
\hline
\end{tabular}




\begin{tabular}{|c|c|c|c|c|c|}
\hline & & & $\begin{array}{l}\text { organizations; prospects of the } \\
\text { industries in } \\
\text { which the counterparties } \\
\text { operate; and actual and forecast } \\
\text { economic } \\
\text { information }\end{array}$ & & \\
\hline EasyJet & No & No & No & No & No \\
\hline $\begin{array}{l}\text { El Al Israel } \\
\text { Airlines }\end{array}$ & $\begin{array}{l}\text { No change to pre-IFRS } \\
9 \text { disclosed criteria }\end{array}$ & No & No & No & No \\
\hline Emirates & $\begin{array}{l}\text { Financial difficulty and } \\
\text { inability to meet } \\
\text { obligations }\end{array}$ & No & No & No & No \\
\hline EVA Air & $\begin{array}{l}\text { More than } 365 \text { days } \\
\text { past due or } \\
\text { unlikelihood to pay } \\
\text { obligations in full }\end{array}$ & No & No & Yes & No \\
\hline $\begin{array}{l}\text { Finnair } \\
\text { International }\end{array}$ & No & No & No & No & No \\
\hline $\begin{array}{l}\text { Airlines } \\
\text { Group }\end{array}$ & No & No & No & No & No \\
\hline $\begin{array}{l}\text { Lufthansa } \\
\text { Group } \\
\text { Norwegian }\end{array}$ & No & Yes & No & No & No \\
\hline $\begin{array}{ll}\text { Air } & \text { Shuttle } \\
\text { Asa } & \end{array}$ & No & No & No & No & No \\
\hline Qantas & No & No & $\begin{array}{l}\text { Including but not limited to } \\
\text { external ratings, audited } \\
\text { financial statements, } \\
\text { management accounts and cash } \\
\text { flow projections and available } \\
\text { press information about } \\
\text { customers) and applying } \\
\text { experienced credit judgment }\end{array}$ & No & No \\
\hline $\begin{array}{l}\text { Qatar } \\
\text { Airways }\end{array}$ & $\begin{array}{l}\text { A failure to pay within } \\
\text { contractually due days }\end{array}$ & No & No & Yes & No \\
\hline Ryanair & No & No & No & No & No \\
\hline SAS & No & No & No & No & No \\
\hline $\begin{array}{l}\text { Singapore } \\
\text { Airlines }\end{array}$ & No & Yes & $\begin{array}{l}\text { Significant financial difficulties } \\
\text { of the debtor, probability that } \\
\text { the debtor will enter bankruptcy } \\
\text { or financial reorganization, } \\
\text { default, or delinquency in } \\
\text { payments }\end{array}$ & No & No \\
\hline $\begin{array}{l}\text { Turkish } \\
\text { Airlines }\end{array}$ & $\begin{array}{l}\text { Unlikelihood to pay } \\
\text { obligations in full, } \\
\text { without recourse, such } \\
\text { as realizing security }\end{array}$ & No & No & Yes & No \\
\hline $\begin{array}{l}\text { Virgin } \\
\text { Australia }\end{array}$ & No & No & No & No & No \\
\hline West Jet & No & No & No & No & No \\
\hline Wizz Air & No & No & No & No & No \\
\hline
\end{tabular}

Note. "No" means no disclosure, or that no customized definition has been found other than quoting or rephrasing IFRS 9 language.

The conclusion that comes out of Table 3 is that the degree of specific application that IASB (2019), IFRS 9 requires for the definition and use of default does not appear to have been fully received, or at least made 
sufficiently intelligible through disclosure to the financial statement readers, although companies have tried to implement their own definition of default, as required by IASB (2019), IFRS 9, much more than they did under IASB (2014), IAS 39, or used the rebuttable presumption simplification. However, still a good half of them do not disclose a definition of default or use boilerplate IASB (2019), IFRS 9 wordings. The picture that emerges is a situation of apparently insufficient disclosure and/or development of an accounting policy for a company's specific facts and circumstances. This is even more evident from a generally poor customized definition of what triggers a significant change in the risk of default since initial recognition.

In conclusion, the theoretical aspects discussed in the paper are of general reach, and the analysis can be replicated to other industries and sectors. However, as this research focuses on a sample of IFRS preparers in the airline industry, its findings cannot be generalized to industries with substantial different characteristics. As several airlines disclose, the credit risk of trade and other receivable in the air transport is limited due to automated invoicing and settlement processes through bilateral arrangements or via the International Air Transport Association (IATA) clearing house, as well as by commercial obligations required of ticketing agents by the IATA. The findings of this articles are important as they investigate how three important theoretical aspects of one of the most disputed standards in recent years have played in company practice. They also add to studies on the airline industry, which have not yet explicitly and extensively covered the IASB (2019), IFRS 9 adoption in that sector. Of course, the theoretical solution of IASB (2019), IFRS 9 technical accounting aspects does not hinge on the way a specific sector has implemented IASB (2019), IFRS 9, but company practice can give a direction of issues companies have found and the link to their conceptual significance for the standard.

\section{References}

Abad, J., \& Suarez, J. (2017). Assessing the cyclical implications of IFRS 9 - A recursive model. Occasional Paper Series, 12 (July). European Systemic Risk Board. https://doi.org/10.2849/2685

Aranda da Rocha Branco Alcantara Alves, A. T., Ribeiro Bordin, M. P., Gonzales, A., \& De Almeida, F. (2020). The impact from adapting of the IFRS 9 (CPC 48) on expected credit losses (ECL) in Brazilian energy companies. Revista Ambiente Contábil, 12(1), 21-43. https://doi.org/10.21680/21769036.2020v12n1ID19616

Bellandi, F. (2019). Leased Aircraft Maintenance Reserves: Comprehensive Framework to Unsolved Issues under IFRS 16 and Topic 842. International Journal of Business and Management, 14(11), 27-54. https://doi.org/10.5539/ijbm.v14n11p27

Bushman, R. M., \& Williams, C. D. (2012). Accounting discretion, loan Loss provisioning, and discipline of banks. Journal of Accounting and Economics, 54, 1-18. https://dx.doi.org/10.2139/ssrn.1521584

Camfferman, K. (2015). The Emergence of the 'Incurred-Loss' Model for Credit Losses in IAS 39. Accounting in Europe, 12(1), 135 . https://doi.org/10.1080/17449480.2015.1012526

Cohen, L. J., Cornett, M. M., Marcus, A. J., \& Tehranian, H. (2014). Bank earnings management and tail risk during the financial crisis. Journal of Money, Credit and Banking 46(1), 171-197. https://doi.org/10.1111/jmcb.12101

European Banking Authority. (2018). First Observations on the Impact and Implementation of IFRS 9 by EU Institutions. Retrieved from http://www.eba.europa.eu

Financial Reporting Council. (2018). IFRS 9 Thematic Review: review of Interim Disclosures in the First Year of Application. Retrieved from https://www.frc.org.uk/getattachment/4998f20e-30e1-47a8-a9e7f15654fa0e03/IFRS-9-thematic-final.pdf

Gebhardt, G. (2016) Impairments of Greek Government Bonds under IAS 39 and IFRS 9: A Case Study. Accounting in Europe, 13(2), 169-196. https://doi.org/10.1080/17449480.2016.1208833

Giner, B., \& Mora, A. (2019). Bank Loan Loss Accounting and its Contracting Effects: The New Expected Loss $\begin{array}{lllll}\text { Models. Accounting } & \text { 726-752. }\end{array}$ https://doi.org/10.1080/00014788.2019.1609898

Gomaa, M., Kanagaretnam, K., Mestelman, S., \& Shehata, M. (2019). Testing the efficacy of replacing the incurred credit loss model with the expected credit loss model. European Accounting Review, 28(2), 309-334. https://doi.org/10.1080/09638180.2018.1449660

International Accounting Standards Board. (2014). International Accounting Standard 39, Financial instruments: Recognition and Measurement - as amended (IAS 39). Retrieved from http://www.ifrs.org 
International Accounting Standards Board. (2018). International Accounting Standard 10, Events after the Reporting Period - as amended (IAS 10). Retrieved from http://www.ifrs.org

International Accounting Standards Board. (2019). International Financial Reporting Standard 9, Financial instruments - as amended (IFRS 9). Retrieved from http://www.ifrs.org

Knežević, G., Pavlović, V., \& Vukadinović, P. (2015). IFRS 9 and implications of "business model vs. management intent" criteria on the quality of accounting information. Conference Paper. https://oi.org/10.15308/finiz2015-22-26

Löw, E., Schmidt, L. E., \& Thiel, L. F. (2019). Accounting for financial instruments under IFRS 9 -First-time application effects on European banks' balance sheets. EBI Working Paper Series, no. 48. https://doi.org/10.2139/ssrn.3462299

Mechelli, A., \& Cimini, R. (2020a). The effect of corporate governance and investor protection environments on the value relevance of new accounting standards: the case of IFRS 9 and IAS 39. Journal of Management and Governance. https://doi.org/10.1007/s10997-020-09551-9

Mechelli, A., Sforza, V., \& Cimini, R. (2020b). Dall'incurred-loss model all'expected-loss model: profili teorici ed analisi di impatto in sede di first-time adoption dell'IFRS 9. Rivista Italiana di Ragioneria e di Economia Aziendale, 1, 7-23. https://doi.org/10.17408/RIREAAMVSRC010203042020

Morris, D., Kang, H., \& Jie, J. (2016). The determinants and value relevance of banks' discretionary loan loss provisions during the financial crisis. Journal of Contemporary Accounting \& Economics, 12(2), 176-190, https://doi.org/10.1016/j.jcae.2016.07.001

Seitz, B., Dinh, T., \& Rathgeber, A. (2018): Understanding loan loss reserves under IFRS 9: A simulation-based approach. Advances in Quantitative Analysis of Finance and Accounting, 16, 311-357. https://doi.org/10.6293/AQAFA.201812_16.0010

Stander, Y. (2021). Quantifying the sources of volatility in the IFRS 9 impairments. South African Journal of Accounting Research. https://doi.org/10.1080/10291954.2021.1885242

Zaman Groff, M., \& Mörec, B. (2021) IFRS 9 transition effect on equity in a post bank recovery environment: the case of Slovenia, Economic Research-Ekonomska Istraživanja, 34(1), 670-686. https://doi.org/10.1080/1331677X.2020.1804425

\section{Copyrights}

Copyright for this article is retained by the author(s), with first publication rights granted to the journal.

This is an open-access article distributed under the terms and conditions of the Creative Commons Attribution license (http://creativecommons.org/licenses/by/4.0/). 